\title{
Robot dogs, interaction and ludic literacy: Exploring smart toy engagements in transgenerational play
}

\author{
Katriina Heljakka \& Pirita Ihamäki
}

\begin{abstract}
:
This article highlights a study focusing on playful human-robotics interaction with an interest in robot dogs, technologically enhanced play, and ludic literacy. In order to find out how players of different ages react to, approach and employ a robot dog (called Golden Pup) in play, we designed an experimental study with 6-7 year old preschool children and $80+$ year old seniors. We conducted the study with preschoolers and seniors, who during a playtest session interacted with a toy robot, namely a smart toy dog resembling a golden retriever puppy. Our aim was to find out how the toy robot invites playful interaction with it, facilitates social engagement between generations of players, and opens up conversations around social robotics and adaptive learning on toy-based technologies between players of different ages. Our findings suggest the role and importance of play in media education and show how robotic toys can be used to enhance ludic literacy, when shared as a part of transgenerational play.
\end{abstract}

Keywords:

human-computer interaction; ludic literacy; robotics; toy-based learning; transgenerational play. 


\title{
Cães robôs, interação e literacia lúdica: Explorar os compromissos de brin- quedos inteligentes na brincadeira transgeracional
}

\begin{abstract}
Resumo: Este artigo destaca um estudo que se centra na interação lúdica humano-robótica com um interesse em cães robôs, brincadeira tecnologicamente otimizada e literacia lúdica. A fim de descobrir como os jogadores de diferentes idades reagem, abordam e utilizam um cão robô (chamado Golden Pup) na brincadeira, concebemos um estudo experimental com crianças pré-escolares de 6-7 anos de idade e idosos com mais de 80 anos. Realizámos o estudo com crianças pré-escolares e idosos que, durante uma sessão de teste de jogo, interagiram com um robô brinquedo, neste caso, um cão brinquedo inteligente semelhante a um cachorro Golden Retriever. O nosso objetivo era descobrir como o robô brinquedo convida à interação lúdica com o mesmo, facilita o envolvimento social entre gerações de jogadores e abre portas a conversas sobre robótica social e aprendizagem adaptativa em tecnologias baseadas em brinquedos entre jogadores de diferentes idades. Os nossos resultados sugerem o papel da importância da brincadeira na educação para os media e mostram como os brinquedos robóticos podem ser usados para aumentar a literacia lúdica, quando partilhados como parte do jogo transgeracional.
\end{abstract}

Palavras-chave: interação humano-computador; literacia lúdica; robótica; aprendizagem baseada em brinquedos; brincadeira transgeracional.

\section{Perros robot, interacción y alfabetización lúdica: Explorando la interacción con juguetes inteligentes en el juego transgeneracional}

Resumen: Este artículo presenta un estudio centrado en la interacción lúdica persona-robot con un gran interés en los perros robot, el juego mejorado con la tecnología y la alfabetización lúdica. Con el fin de descubrir cómo los jugadores de distintas edades reaccionan, se acercan y emplean un perro robot (llamado Golden Pup) en el juego, hemos diseñado un estudio experimental con niños de preescolar (6-7 años) y personas mayores de 80 años. Hemos llevado a cabo el estudio con niños en edad preescolar y personas mayores, quienes interactuaron con un robot de juguete, concretamente un perro de juguete inteligente similar a un cachorro de golden retriever, durante una sesión de juego de prueba. Nuestro objetivo era descubrir cómo el robot de juguete invita a la interacción lúdica con él, facilita el compromiso social entre jugadores de varias generaciones e inicia conversaciones en torno a la robótica social y el aprendizaje adaptativo sobre tecnologías basadas en juguetes entre jugadores de distintas edades. Los resultados sugieren la importancia del juego en la educación mediática y muestran cómo pueden utilizarse los juguetes robot para mejorar la alfabetización lúdica al compartirla como parte de un juego transgeneracional.

Palabras clave: Interacción persona-máquina, alfabetización lúdica, robótica, aprendizaje basado en juguetes, juego transgeneracional.

\section{Chiens-robots, interaction et thérapie par le jeu: Découvrir les engagements des jouets intelligents dans des jeux transgénérationnels}

\begin{abstract}
Cet article porte sur une étude axée sur les interactions entre les robots et les humains qui ont un intérêt particulier pour les chiens-robots, les expériences de jeux technologiquement améliorées et la thérapie par le jeu. Afin de découvrir comment les participants de différents âges réagissent, s'approchent et utilisent un chien-robot (appelé Golden Pup) dans le jeu, nous avons conçu une étude expérimentale avec des enfants d'âge préscolaire entre 6 et 7 ans, et des seniors âgés de 80 ans et plus. Nous avons réalisé l'étude avec des enfants d'âge préscolaire et des personnes âgées qui, au cours d'une séance de test de jeu, ont interagi avec un robot jouet, à savoir un chien joue intelligent ressemblant à un chiot Golden Retriever. Nous cherchions à découvrir comment le robot jouet invite à une interaction ludique avec lui, facilite l'engagement social entre générations de joueurs, et suscite des conversations sur la robotique sociale et l'apprentissage adapté des technologies du jouet entre joueurs d'âges différents. Les conclusions de l'étude suggèrent le rôle important que revêt le jeu dans l'éducation médiatique et montrent comment les jouets robotiques peuvent être utilisés pour améliorer la thérapie par le jeu, lorsqu'ils sont partagés dans le cadre d'un jeu intergénérationnel.
\end{abstract}

Mots-clés: interaction personne-machine; thérapie par le jeu; robotique; apprentissage par le jouet; jeu transgénérationnel. 


\section{Introduction}

The economist Jeremy Rifkin states that "play is becoming as important in the cultural economy as work was in the industrial economy" (Rifkin, 2000, p. 263). Playfulness has gradually become a central category of our culture (Raessens, 2010). This cultural development also recognized as the ludification of culture has had an effect on the broadening of user groups of play-related products and services. In fact, Zygmunt Bauman argues that playfulness in our ludic society is no longer confined to childhood but has become a lifelong attitude: "The mark of postmodern adulthood is the willingness to embrace the game whole-heartedly, as children do" (Bauman, 1995, p. 99). Then it is no surprise that state-of-the-art technologies are being experimented with, especially in the categories of various playthings - toys and games.

Following Bauman's (1995), Rifkin's (2000) and Raessens' (2010) ideas on the emergence of a ludic society, we constructed an exploratory study on transgenerational toy play with a robot dog. Pets have long been an important part of children's lives, offering comfort and companionship, and promoting the development of responsibility (Beck \& Katcher, 1996; Kahn, 1999; Kahn \& Kellert, 2002; Melson, 2001; Myers, 1998). During recent years, there has been a movement to create technological substitutes for pets, such as robot toys (for example, I-Cybie, AIBO, Tekno Robotic Puppy, and PooChi). Our research presented in the article at hand, focuses on investigating preschool children's and elderly peoples' interaction and transgenerational play with a robot dog called Golden Pup. We are interested to know how preschool children and seniors, who meet at a day activity center respond to and interact with the robot dog and to find out what kind of play(ful) experiences the robot dog will offer the preschool children and elderly. The use of robotic toys in connection to transgenerational play, like in this case study the employment of the Golden Pup (recommended for ages 5-105 years), is envisioned to create novel and meaningful play situations employing sound, haptic movements and realistic visualization. Furthermore, in our study, interaction with the robot dog is also considered from the perspective of ludic literacy.

\section{Smart toy-technology and young children}

The educational realm is rapidly transforming as digital and connected technologies are finding their way to the contexts of early education. Learning is not only being gamified, but also toyified, as technologically enhanced toys, such as Internet-connected toys (or loToys) and smart toys, enter preschool and primary school (Heljakka \& Ihamäki, 2018).

Despite rapid developments in the media landscape of toys, and the emergence of toyified technologies, physical (tangible) toys and games are still popular among different age groups. Increasingly, however, these playthings come enhanced with digital 
features. As Zenvenbergen (2007) notes, one only has to consider the toys produced by global toy manufacturers and the changes over the past 20 years to see how digital technologies are changing the experiences of children. For children growing up in an increasingly digitized and ubiquitously connected environment, ways of acting and being in the social world are framed by experiences with these technologies, for example, mobile devices and connected toys. Nowadays, young children's toys contain more sophisticated technology in comparison with their parents' traditional (and in many cases non-digital) toys, for example, the mechanically moving 'toy friends' of previous times. In today's world, these interactive toys, also labelled as smart toys, are more persuasive than ever in their ways of inviting players into interaction, care-taking, and communication (Heljakka \& Ihamäki, 2019). Together with a computing and communication capability, their connectivity in many cases is so well integrated with the plaything that it becomes a "technology that disappears" (Satyanarayanan, 2001).

The category of interactive toys has a long history as the first smart toys were developed over a hundred years ago when Thomas Edison adopted his wax-cylinder phonograph to create the first popular talking toy. Until 1998, these mechanical inventions were limited to only a handful of phrases. During the late 1990s, the world was introduced to Furby, a new type of smart toy. Suddenly, writes Pesce (2000, p. 5), "the toy talking to a child has its own language (Furbish), has the ability to compose simple sentences, and responds to a number of verbal and physical commands".

Although the border between actual robots and contemporary, anthropomorphized toy robots seems to be blurring, one way to distinguish these two groups of "relational artefacts" (Turkle et al. 2006) is their accessibility for the playing audience. Whereas robot-characters have started to make their entry into institutions of pedagogy and healthcare, the development of using artificial intelligence to entertain and educate the human being is still in its infancy. One exception to this are smart and interactive toys, such as toy robots. Despite their complex technological systems, smart toys designed for the mass market come in relatively affordable prices for consumers of the Western world and are in this way more likely to enter the domestic playscapes of young children. For example, sales of connected toys are expected to triple over the next five years (Juniper Research, 2017, c.f. in Taylor \& Gummer, 2019).

\section{Ludic literacy}

Media literacy arises from the interface and interaction between media and user (Park, 2017). Our digital technologies have changed rapidly over the last decade, which is related to a developed view on literacy as proposed in earlier literature. For example, ICT literacy, information technology literacy, media literacy, online literacy, multimedia literacy and new literacies (for reviews, see Markauskaite, 2006). 
In our understanding, this list of literacies should be complemented with ludic literacy. As stated by Mäyrä (2016), ludic literacy includes understanding of (a) technology, (b) culture, and (c) social dimensions of games and play-capabilities to step within a game, interplay with others, and being creative within those frames (Mäyrä, 2016). Contemporary toys, a multidimensional and multiplatform media in themselves, call out for improved understandings around media literacy. In fact, earlier research states the necessity for ludic literacy in association with toys (Heljakka \& Ihamäki, 2018).

Ludic literacy enables learners of different ages to develop their capacity in grasping the affordances and related meanings associated with intelligent play-objects, or smart and in many cases, character-based 'toy friends'. These toys invite interaction of many kinds, generating both multi-sensory and cognitive experiences. For example, many new toys use sound, lights, movement, and language-based communication to encourage players to engage physically and creatively. To fully grasp what playful interaction with a technologically-enhanced toy, such as a robot dog means, engagement with this type of smart toy requires new literacies from its players.

To develop a firsthand understanding of human-robot toy interactions with a robot dog, we designed and conducted an exploratory study including preschool children and seniors at a day activity center, who were interviewed and observed during a playtest in Finland in the summer of 2019. The authors study the responses of seniors and preschool-aged children to the persuasion strategies of a robot dog as presented in a playtest and group interview situation. One of the main goals was to find out how elderly people react and playfully interact with the toy robot. In particular, what guided our interest was our curiosity about the toy's persuasion strategies in terms of its capacity to promote social and transgenerational play. Another criterion for the robot toy was that it represents a multi-dimensional experience. The selected robot dog represents a 'toy friend', which, through its physical appearance and 'huggability', calls out for friendly (tactile and mobile) interaction through voice-recognition and sensors. In this way, the toy encourages both the child and the adult as a player to engage and interact with it.

This article is structured in the following way: We begin with a discussion on earlier research, first, demonstrating the evolution of interactive toys, and second, by presenting some earlier studies in this field. We then go on to explain the method of our own study, describe the playtest, discuss the results, and finally, conclude the article with a reflection of our findings.

\section{Earlier Research}

A significant part of the research on contemporary smart and connected toys concentrates around data privacy issues, for example, on the 2015 'Hello Barbie hack', in which security researchers were able to remotely access the doll's microphone and 
record children's conversations (Gibbs, 2015). Although this branch of research represents an important one, our perspective takes a different approach, an interest in playful interaction with the robot dog and the capacity of the toy to facilitate ludic literacy. Play is the paragon of enjoyable, intrinsically motivated activity associated with a wide range of positive effects on motivation, social interaction, learning and experiences. As described by Deterding (2016) toys and games are artefacts purpose-built to afford play and its positive effects.

In this case study, we understand play to give children and elderly players positive experiences and motivation to interact with a robot dog as a part of their imaginative and tactile experiences. As children's play culture is largely affected by digital (and often screen-based) technologies and even play with traditional physical artefacts (i.e. object play) is enhanced and extended with the use of mobile devices and sharing of play on social media, the ideas of dematerialization and digitalization prevail. Paralleling this development, some popular beliefs, especially communicated in discourses in media texts, accentuate that children play less with physical toys, that children play less outdoors and that children play more (digital) games and less with (traditional) toys. At the same time, the multidimensional and multimaterial nature of popular physical playthings, such as contemporary character toys (dolls, action figures and soft toys) is undeniable. Animal toys, especially, are one of the key categories of character toys that attract children of kindergarten age (Ruckenstein, 2013). According to observations made in earlier research (e.g. Heljakka \& Ihamäki, 2019), playing with physical character toys still represents a popular type of object play among preschool-aged children.

\section{Interactive toy friends and play value}

Kaplan $(2000,2005)$ argues that robotic toys are designed to be 'useless' in the sense that they do not perform any tasks or service for users. We believe, however, that toy robots just like any smart toys introduced during the past decennia, may 'serve' their players in delivering play value to their users, which is built either on purely entertainment-oriented play possibilities, or on the educational value, which the toys may convey either as part of informal, or formal learning environments of young children. Moreover, the smart toys may be designed to function as educational tools (or, edutainment), which means that they are given learning affordances modelled as entertaining experiences. Examples of such smart toys include Dash by Wonder Workshop (2014) and Smart Bear by Fisher-Price (2015).

Previous research on technologically enhanced character toys that demand nurturing are represented by examples such as Tamagotchi (1996), Furby (1998), and My Real Baby (2000). Two early examples of commercial robotic toys are the aforementioned Furby and the ActiMates Barney (1997). More recent work conducted by, for example, Fernaeus et al. (2010) present Pleo (2007), an interactive toy and a robotic dinosaur, 
and discusses imaginative play with this robot toy. The researchers looked upon Pleo in terms of development and lifecycle and showed how maintenance became a central aspect of keeping and using Pleo.

\section{Robotic pets and Natural Interfaces (NUI)}

Apart from smart, interactive toy robots with educational affordances, there has been a trend of developing robot toys that look and act like pet animals and that respond to nurturing. Examples include the Sony AIBO robotic dog and Ugobe's Pleo, which are designed in line with the thought of functioning as artificial pets or artificial life forms. Both AIBO and the aforementioned Pleo dinosaur are claimed to develop a 'personality' and these toys have the possibility to update (Fernaeus et al., 2010). Paro (Shibata \& Tanie, 2001) and the Huggable (Stiehl et al., 2006) are two examples of robotic toy animals, with the physical appearance of a baby seal and teddy bear respectively. Both Paro and the Huggable come with haptic sensors to be able to interact with people in primarily therapeutic or educational settings. Paro has been awarded as the World's Most Therapeutic Robot certified by the Guinness World Records (http:// www.parorobots.com/).

Researchers and toy designers have understood that the natural interfaces (NUI) are the most appropriate for the interaction of children because they allow the children to interact with a computer application through natural capabilities such as voice commands and allowing, for example, the robot toys to move. Again, tangible technologies allow the interaction and manipulation of digital information that is communicated through physical objects like toys (Ishii et al., 1997). Tangible technologies include multi-touch surfaces, smartphones, tablets, robots ad technologically-enhanced toys (like the Internet of Toys, or loToys and robot toys) among others (Nácher-Soler et al., 2015).

The Golden Pup employed in our study, represents interactive technology of this kind. In our case study, the Golden Pup robot toy has similarities with the seal robot Paro. For example, the Golden Pup has sensors that respond to touch and sounds. "You can feel the heartbeat while touching it and it can respond back to your voice commands", the description of the Golden Pup says (Joy for All Companion Pets, Golden Pup, Amazon 2019).

\section{Method}

The following section of the article highlights the firsthand stage of a study conducted in the summer of 2019 in the context of a Finnish elderly day activity center and preschool environment. Here, our interest turns to transgenerational play, meaning play between different generations or "activity across generations", also conceptualized as 
intergenerational play. Transgenerational play with contemporary technologies meant for play purposes must be critically evaluated. For example, previous research indicates that the controls of a console game presents barriers to the older, less experienced players (e.g. Aarsand et al., 2007, p. 244 c.f. in Taylor \& Gummer, 2018). We will therefore analyse from the group-interview and playtest session whether similar barriers are present when a robot toy including hidden-technology is being played with by a group of players, who more often play with tangible objects which more closely resemble traditional, physical toys (for reference, see e.g. Taylor \& Gummer, 2018).

\section{Participants}

According to Ruckenstein (2010) the Nordic discourse on digital toys often constructs these toys as unnatural intrusions into the lives of small children. However, as previous research illustrates (Heljakka \& Ihamäki, 2018; Heljakka \& Ihamäki, 2019), there is interest in the context of early education to find out, how smart toys could be used as a part of edutainment - a combination of playful learning that is both guided and structured, and in parallel to this, also used as part of free-time play within preschool. In this case study, the preschoolers who joined our research, are based at a kindergarten facility that is adjacent to a day activity center for seniors. They frequently interact with the elderly to join transgenerational activities. We used the opportunity to recruit individuals from both groups in our study interested in transgenerational play with a robot dog. Altogether, some $(n=7)$ preschoolers aged $6-7$ years, and $(n=11)$ seniors aged $80+$ years joined our study.

\section{Group interviews and playtest}

We have used a playtest (altogether 1 hour 30 minutes in length), which was started by a group-interview session with the elderly people and preschoolers. To begin, the researchers introduced topics for discussion concerning domestic animals and pets, such as who has had a pet previously or who has a pet at the present, what kind of pet it was or is, what is the pet's name, what kind of memorable experiences the pet(s) have offered the participants, etc. After discussing these topics for some 30 minutes, one of the researchers introduced the seniors and preschoolers to the robot dog Golden Pup and allowed the participants to play with the robot toy. Each member of the focus group had some time to engage and interact with the Golden Pup. After the transgenerational group-interview and playtime session, the children were taken back to the nearby preschool facility and were asked to draw how they would like to play with the Golden Pup. 

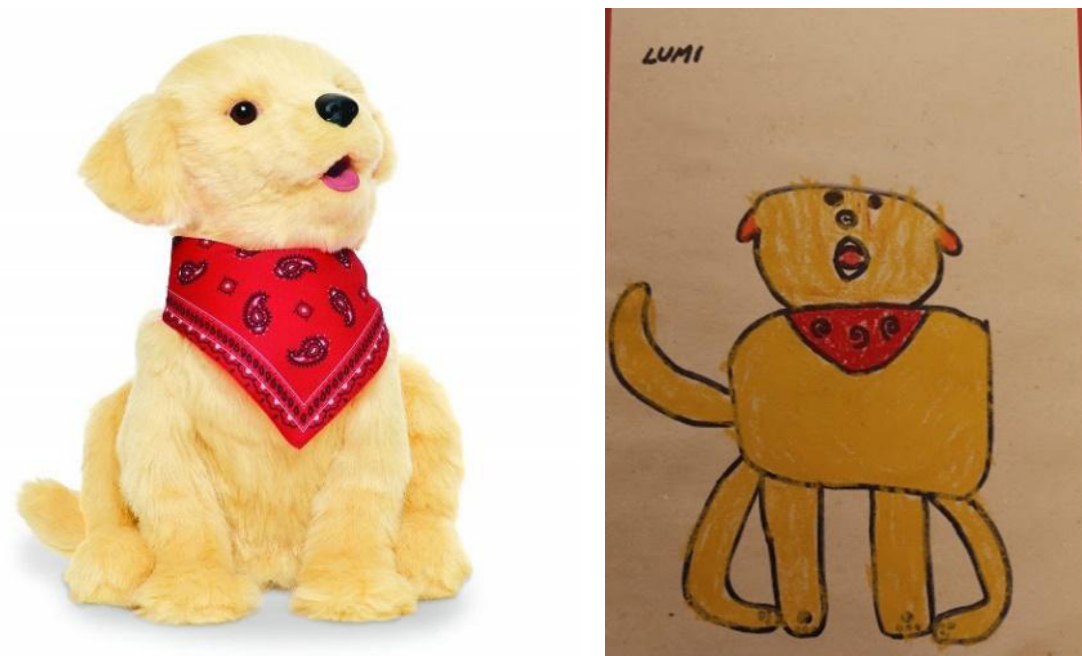

Figures 1-2. Golden Pup robot dog by Joy for All (on the left). A preschooler's drawn interpretation of the robot dog (right).

\section{Companion Pet Golden Pup}

"This pup looks, feels, and sounds like a real dog. Its thumping heartbeat enhances its life-like qualities. This beautiful, soft dog responds to petting, hugging, and motion much like the dogs you know and love, without the care issues." (Joy for All Companion Pets, Golden Pup, Amazon 2019). The envisioned play patterns of the chosen dog toy robot represents according to the toy marketer mobile play: The Golden pup reacts to touch "with puppy-like movements and sounds"; haptic/object play: The Golden pup features a "realistic coat"; and auditive play: The Golden Pup comes with a "simulated heartbeat, and authentic sounds and responds to sounds with 'Bark Back' technology". Despite its complex hidden technology, the Golden Pup is a non-connected toy. 


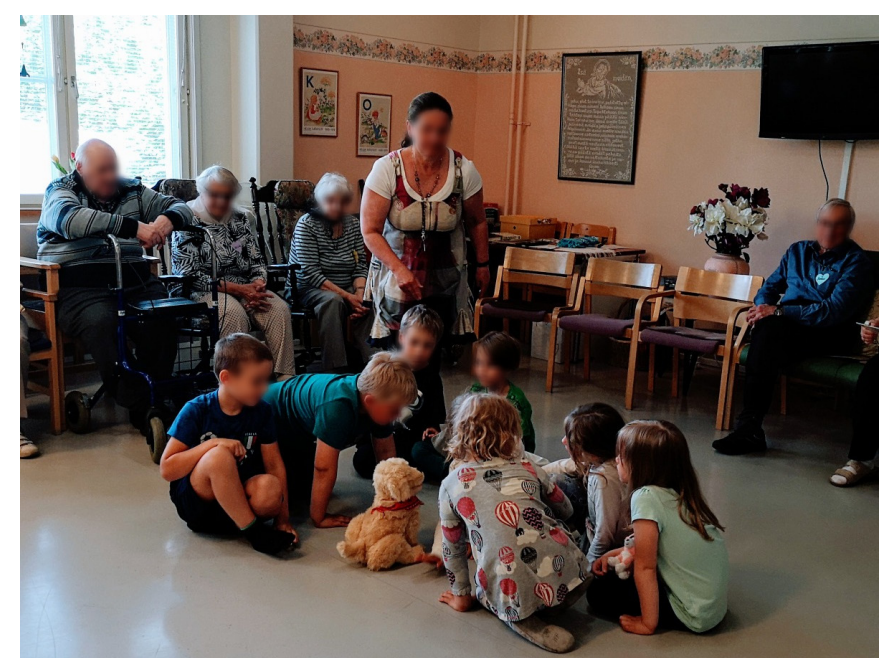

Figure 3. Children interact with the Golden Pup robot dog as the seniors are watching.

\section{Results}

\section{From Real Pets to Human-Robot Interaction}

Turkle et al. (2006) write about the child's point of view in accepting the caretaker's role, which the researchers see as a crucial step in creating a bond with an inanimate object. A central aspect of the formation of this bond is the child's immersion in the belief of understanding the character's "inner state," that is, its desire to interact with its player and learn from this interaction (Heljakka \& Ihamäki, 2019).

In order to be able to understand the potentialities of current toys, empirical engagement with their primary users (or, rather, players) is needed. The goal of our study was to explore the human-robot interaction between preschoolers, seniors and the Golden Pup robot dog.

In the group interview session, the authors introduced the Golden Pup to the children, first by showing the toy for the group of children and then letting each child interact with it. Our approach was to interfere as little as possible in these engagements. Participants, both preschoolers and seniors, had the possibility to discuss and play together with the Golden Pup, while one researcher acted as facilitator, another researcher made observations, and a third person video-recorded the visit. The observer kept in the background but joined the conversation when it felt natural.

Before the participants were allowed to play with the toy robot, they were asked about their general experiences with domestic animals (farm animals and pets), both in the past and in the present. Most of the seniors had had a contact with both animal types in their personal lives, and most of them commented that animals played a significant 
part of their childhood. However, in many cases, animals acted a normal part in the lives of these people, who mostly had spent their childhood living at farms. In many such domestic environments dogs and cats served a purpose and were not necessarily simply treated as pets or companions and 'play partners' as we know them nowadays. When the discussions turned to the lives of the seniors as they live their lives now, the comments were often critical - the limited size of living spaces and the pure exhaustion of owning living pets was considered an obstacle for not being able to cater for real pets. Also, how their peers 'keep' their pets, raised some concerns. For example, one elderly person literally said that: "A dog is not a toy for the elderly". Another claimed: "Dogs do not belong to apartment buildings". Nevertheless, the reminiscing around dogs and cats as a part of their former lives prompted positive and emphatic responses in the elderly. Many said that they wished to own a pet, if it only was possible for them.
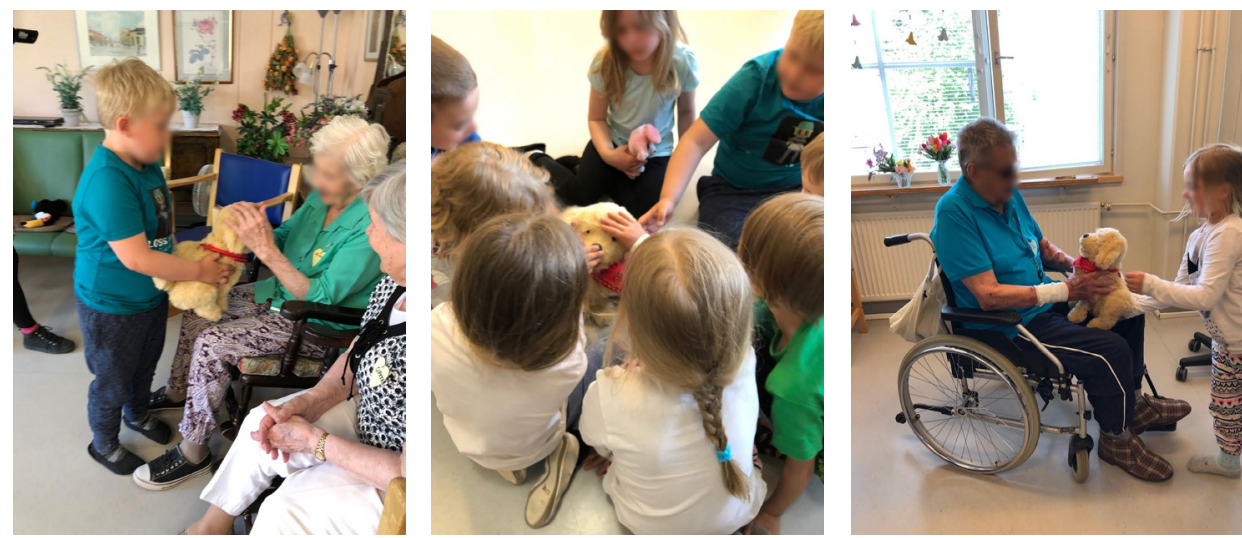

Figures 4, 5, and 6. Children interact with the Golden Pup robot dog and introduce it to seniors.

Considering the children, the ones who currently have pets as family members, were in the minority. The preschool-children reported in general to have had good relations to their pets, playing with them and treating them as companions. When the group was introduced to the Golden Pup, both the preschoolers and the seniors responded with interest and excitement. First, the preschoolers gathered on the floor to each take their turn to interact with the Golden Pup. Meanwhile, the seniors watched this interaction (see Figure 3.). After this, two preschoolers took turns to take the robot toy to each of the seniors so that they could hold the Golden Pup and to test its reactions.

Results of the present study demonstrate that elderly people were enthusiastic with the robot toy, they engaged actively with the robot dog, even played with it (made physical contact and talked to it) as if it was a real pet.

Moreover, the preschool children expressed a positive attitude toward the robot dog and the occasion to transgenerational play with the toy and the elderly people. 
More support for the engaging value of our playtesting comes from results of the content analysis of the verbal responses made by the study participants. For many elderly people, the Golden Pup toy robot triggered memories of past feelings of comfort. Also, many of the elderly participants as well as the preschoolers wanted the robot dog to stay with them in the day activity center or kindergarten.

In the light of the findings of our exploratory study, the Golden Pup can be seen to fit to be employed as a part of transgenerational play, because it is easy to use (it only needs a battery and to be switched on) and it includes hidden technology and in this way, thanks to its natural interface, promotes an intuitive way to interact with it. Additionally, the robot dog simulates a real dog's heartbeat, eye movements, head movements and dog sounds, which makes the robot dog appear very realistic. For instance, in our study, one of the child participants even asked: "Is it a real dog?"

After the group interview session, the children were asked to draw a picture of the Golden Pup and to explain, how they would like to play with it. Drawings made immediately after the play session showed, how the preschoolers expressed an interest to interact with the dog in many ways (see Figures 7-8).

\section{Ludic Literacy and Interaction with Toy Robots}

Sutton-Smith (1986) emphasizes the need for understanding toys as an "object alphabet" for the very young. Toy literacy, in a contemporary sense, does not only imply understanding of the material, but increasingly, the technological: It has come to refer to the capacities of toys that are mediated through digital and computerized technologies. In other words, the physical toy is increasingly enhanced with 'hidden' technological features or natural interfaces, or when connected, with apps and use of social media platforms.

In order to function in this new media environment, people of different ages need digital awareness, competence, and skills to participate in this digital world, including knowhow in using different technologies by understanding their features. Moreover, as proposed in studies conducted by the authors in previous stages of research interested in the technologically-enhanced toys, the use of playthings calls out for ludic literacy skills (Heljakka \& Ihamäki, 2018). In other words, players of toy robots should understand (and embrace) the hidden technology that enables them to play with the toy: That is, to understand the underlying technology and its limitations (what it can and cannot do), and grasp the fact that although anthropomorphised and intuitively interacted with, as in the case of the robot dog, the toy is still an artificial entity, which cannot replace human-to-animal (or, human-to-human) interaction, but can nevertheless offer companionship and comfort while being employed as a part of both imaginative and tactile play.

In this way, the $21^{\text {st }}$ century toy literacy of adults as educators, parents, grandparents, and of the children as players themselves should include this notion and learning 
of ludic literacy, in combination with the use of current technologies of play, such as engagement with toy robots, may they represent pets or 'toy friends' of other kinds.
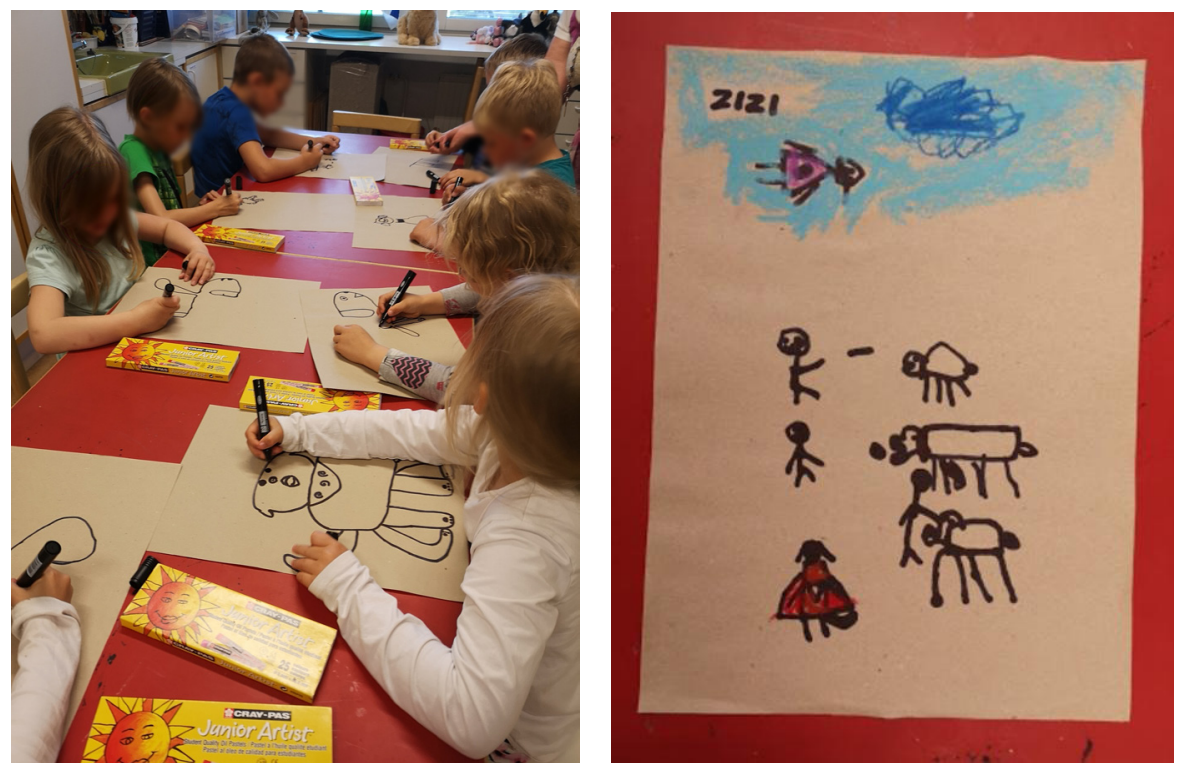

Figures 7-8. (On the left) Children draw their interpretation of the Golden Pup. (On the right) The drawing of a preschooler, who explained that he would like to pet the Golden Pup, to play with a ball with the Golden Pup, and to throw a stick to the Golden Pup.

\section{Conclusions and Future Work}

Currently, the technological aspect of contemporary toy characters is becoming a more normalized part of the toy design process as toy companies try to reach out to preschoolers, toddlers, and even infants. Moreover, the category of smart toys has features that attract mature players. Therefore, it is of crucial importance to investigate the interaction of the children with the technologically-enhanced toys, such as toy robots to know how they as players respond to these character toys and what kind of play experiences these toys may offer in terms of play between generations.

According to our case study described in the article at hand, investigations of robot dogs must include perspectives on the form (character-based resemblance to real pets and natural interface), functions (e.g. physical movement through sensors, audio-based content), and possibilities to connect with the 'toy friend' mediated either through digital or emotional connectivity. In the case of the Golden Pup, both preschoolers and seniors, in their firsthand reactions, seemed to value both the form (aesthetics, or the 'cuteness' of Golden Pup). One the one hand, the preschoolers 
expressed an interest in the robot dog's mechanical functions (physical movement), whereas the seniors seemed to be most interested in the tangible aspects of the robot dog's physiognomy (its soft natural interface). On the other hand, both age groups seemed eager to connect with the toy robot as a play partner, or a companion.

The older generation has become more engaged with technology in recent years (Taylor \& Gummer, 2019). Being toy literate in the $21^{\text {st }}$ century also means that the playing audience is aware of the technologically-enhanced capacities of current toys. Without a basis for understanding how players interact with the hidden technologies of the toy friends that the robot toys represent in play, it is difficult for parents/grandparents, caretakers and teachers to understand the manifold potentialities of these toys. Following this thought, our goal was to investigate transgenerational, playful responses to a toy robot. The study presented in this paper provides an overview of the seniors and preschool children's first responses to a robot dog, Golden Pup.

According to common belief, technologically enhanced toys may lead to more solitary play. On the contrary, following Sutton-Smith's idea: "Toys decrease the sociability of play. We hasten to add, however, that new toys also, in time, make a contribution to social play" (Sutton-Smith 1986, p. 38).

The purpose of the study was to investigate how children and seniors respond and react to a robot dog introduced in a setting allowing transgenerational and social interaction between humans and the toy. Based on the findings of this study, the response of preschoolers aged 6-7 years was as emphatic to the robot dog, as the response from the seniors who joined our study: The Golden Pup was considered "cute" and open for playful engagement: All of the participants wished to engage with the robot dog by physically manipulating it - touching and "petting" it, holding it in their arms and talking to it.

The results show that the key dimensions of the Golden Pup was its welcoming appearance (aesthetics, soundscape and gentle movement) that attracted both the preschoolers and seniors. As Sutton-Smith (1986) reminds us, toys are an agency for the imagination. The children in our study informed us that the robot dog can be played with in many ways, although, for example, its movements are limited. Again, this hindrance was not considered a limitation by the seniors, whose mobility may be equally limited.

On the one hand, when asked, preschoolers reported to be mainly interested in interacting with the toy through engagements demonstrating activities that would be carried out with a normal pet-engaging with it in the name of physical play guided by their imagination; taking it outdoors, giving it toys, playing 'house' with it and generally, treating the toy robot as a furry friend and companion. On the other hand, seniors mainly expressed an interest to tactile play - to 'care' for the toy by holding it close and cuddling, or stroking it.

According to the organizers of the Spielwarenmesse International Toy Fair Nuremberg, digital media looks set to assume a lasting place in the toy industry. A publication from 2013 states that technologically-enhanced toys do not pose a threat but should 
instead be seen as a complement to classical toys (Play it! The Global Toy Magazine, 2013).

Andrew Sixsmith, director of the Science and Technology for Aging Research Institute at Simon Fraser University in Vancouver, British Columbia states that "Pets play an important companion role whatever your age". He means that everyone does not have a possibility to take care of pets, and this is why robotic pets may be the next big thing in, for example, dementia care (Jeffrey-Wilensky, 2019). In order to evaluate their full potentiality as devices that afford rich play patterns for players of different ages, or as a part of transgenerational play, further agency needs to be given to the players - the educators, parents and grandparents, as well as to the playing children and elderly people. These important stakeholders of play should be given agency in informing toy designers and the industries of play, what more they would like future toys to offer them terms of care, companionship, connectedness, as well as cognitively and physically engaging play.

\section{Acknowledgments}

The authors would like to express their gratitude to the preschoolers, their teachers, and seniors (including personnel of the day activity center), who joined this study.

\section{References}

Aarsand, P.A. (2007). Computer and Video Games in Family Life: The digital divide as a resource in intergenerational interactions. Childhood, 14, pp. 235-256.

Bauman, Z. (1995). Life in Fragments. Essays in Postmodern Morality. Oxford: Blackwell.

Beck, A.M. \& Katcher, A.H. (1996). Between pets and people. West Lafayette, IN: Purdue University Press.

Deterding, C.S. (2016). Make-Believe in Gameful and Playful Design. In (Eds.) Turner, P. \& Harviainen, J.T. Digital Make-believe. Human-Computer Interaction (pp. 101-124). Basel Springer.

Fernaeus, Y., Håkansson, M., Jacobsson, M. \& Ljungblad, S. (2010). How do you Play with a Robotic Toy Animal? A long-term study of Pleo, In IDC2010, June 9-12, 2010, Barcelona Spain. Accessed 12 of June 2019, http://bit.ly/2pX7WZo

Gibbs, S. (2015). Hackers can hijack wi-fi Hello Barbie to spy on your children The Guardian. 26.11.2015. Accessed 12 of June 2019, http://bit.ly/2JarBYW

Heljakka, K. \& Ihamäki, P. (2018). Preschoolers Learning with the Internet of Toys: From Toy-Based Edutainment to Transmedia Literacy. Seminar.Net, 14(1), 85-102. Accessed 12 of June 2019 http:// bit.ly/2PtwrZf

Heljakka, K \& Ihamäki, P. (2019). Persuasive Toy Friends and Preschoolers: Playtesting loToys. In (eds.) Mascheroni, G. \& Holloway, D. (2019). Internet of Toys-Practices, Affordances and the Political Economy of Children's Smart Play (pp. 159-178). Palgrave Macmillan.

Ishii, H. \& Ullmer, B. (1997). Tangible Bits: Towards Seamless Interfaces between People, Bits and Atoms, In the Proceedings of CHI 97', March 22-27, 1997, ACM. Accessed 12 of June 2019, http://bit.ly/344AfUx 
Jeffrey-Willensky, J. (2019). Why robotic pets may be the next big thing in dementia care, March 3.4.2019. Accessed 12 of June 2019, https://nbcnews.to/2Jo4spM

Joy for All Companion Pets, Golden Pup, Ageless Innovation Joy For All Companion Pets Golden Lifelike \& Realistic. Amazon, Accessed 12 of June 2019, https://amzn.to/369RC8n

Juniper Research (2017). Juniper Research: Smart Toy Sales to Grow Threefold to Exceed \$15.5 Billion by 2022. Accessed 12 of June 2019, https://prn.to/2p88PP4

Kahn, P. H., Jr. (1999). The Human relationship with nature: Development and Culture. MA: MIT Press.

Kahn, P. H., Jr., \& Kellert, S. R. (2002). (Eds.) Children and Nature: Psychological, Sociocultural, and Evolutionary Investigations. Cambridge, MA: MIT Press.

Kaplan, F. (2000). Free creatures: The role of uselessness in the design of artificial pets. In (Eds.) Chistaller, T., Indiveri, G. \& Poigne, $1^{\text {st }}$ Workshop on Edutainment, Germany.

Kaplan, F. (2005). Everyday robotics: robots as everyday objects. in Soc-Eusai. ACM: Grenoble, France. p. 59-64.

Lieberman, S. (1979). A transgenerational theory. Journal of Family Therapy, 1(3), 347-360.

Markauskaite, L. (2006). Towards an integrated analytical framework of information and communications technology literacy: from intended to implemented and achieved dimensions. Information Research 11(3), 2006. Accessed 12 of June 2019, https://files.eric.ed.gov/fulltext/EJ1104648.pd

Melson, G. F. (2001). Why the wild things are: Animals in the lives of children. Cambridge, MA: Harvard University Press.

Myers, G. (1998). Children and animals: Social development and our connections to other species. Boulder, CO: Westview Press.

Mäyrä, F. (2016). Pokémon GO and the Ludification of Culture. Academic keynote, MindTrek 2016, Accessed 12 of June 2019, http://bit.ly/32OcBvy

Nácher-Soler, V.E.; García Sanjuan, F. \& Jaén Martínez, F.J. (2015). Game Technologies for Kindergarten Instruction: Experiences and Future Challenges. In Proceedings of the II Congresso de la Sociedad Española para las Ciencias del Videojuego (CoSECiVi 2015), Barcelona, Spain 24 June 2015.

Park, J. (2017). Media Literacy, Media Competence and Media Policy in the Digital Age. In Proceedings of the 2017 Arts, Humanities, Social Sciences and Education Conference, January 3-6, 2017 Ala Moana hotel, Honolulu Hawaii, 2017. Accessed 12 of June, http://bit.ly/2pjqDXj

Parorobots, Accessed 31 of October 2019, http://www.parorobots.com/

Pesce, M. (2000). The Playful World: How Technology Is Transforming Our Imagination, New York: Ballantine Books.

Play it! The Global Toy Magazine. (2013). Evolution, not revolution. Spie/warenmesse International Toy Fair Nürnberg publication 30.1.-4.2.2013.

Raessens, J. (2010). Homo Ludens 2.0, The Ludic Turns in Media Theory, Univerisiteit Utrecht, Accessed 10 of June 2019, http://bit.ly/2WjGxNK

Rifkin, Jeremy (2000). The Age of Access. The New Culture of Hypercapitalism, Where All of Life Is a Paid-for Experience. New York: Jeremy P. Tarcher/Putnam. 
Ruckenstein, M. (2010). Toying with the world: Children, virtual pets and the value of mobility. Childhood, 17(4), 500-513.

Ruckenstein, M. (2013). Spatial extensions of childhood: From toy worlds to online communities. Children's Geographies, 11(4), 476-489.

Shibata, T. \& Tanie, K. (2001). Physical and affective interaction between human and mental commit robot. Proceedings of ICRA'01: IEEE. pp. 2572-2577.

Satyanarayanan, M. (2001). Pervasive Computing: Vision and Challenges. IEEE Personal communications, 2001. Accessed 12 of June 2019, http://bit.ly/2BOK7Wp

Stiehl, W. D., Lieberman, J., Breazeal, C., Basel, L., Lalla, L. \& Wolf, M. (2006). The Design of the Huggable: A Therapeutic Robotic Companion for Relational, Affective Touch. In AAAl fall Symposium on Caring Machines: Al in Eldercare, 3-6. November, Washington D.C., Accessed 10 of June 2019, http://bit.ly/365Apgx

Sutton-Smith, B. (1986). Toys as Culture. Gardner Press, New York: NY.

Taylor, A. \& Gummer, A. (2018). Connected Grandparents: Are Smart Toys the Future for Intergenerational Play? 8th International Toy Research Association World Conference, International Toy Research Association (ITRA), Jul 2018, Paris, France.

Wonder Workshop Classroom, Accessed 10 of June 2019, http://bit.ly/2pgBTnq

Zenvenbergen, R. (2007). Digital Natives Come to Preschool: implications for early childhood practice, Contemporary Issues in Early Childhood, 8(1), 19-29.

Katriina Heljakka

Degree Programme in Cultural Production and Landscape Studies University of Turku, Pori, Finland Email: katriina.heljakka@utu.fi

Pirita Ihamäki

Prizztech Ltd.

Pori, Finland

Email: pirita.ihamaki@prizz.fi

Correspondência

Katriina Heljakka

P. Pohjoisranta $11 \mathrm{~A}$

28100 Pori

FINLAND

Data de submissão: Julho 2019

Data de avaliação: Setembro 2019

Data de publicação: Dezembro 2020 